The University of Maine

\title{
DigitalCommons@UMaine
}

Earth Science Faculty Scholarship

Earth Sciences

1979

\section{Himalayan and Trans-Himalayan Glacier Fluctuations Since AD 1812}

Paul Andrew Mayewski

University of Maine, paul.mayewski@maine.edu

Peter A. Jeschke

Follow this and additional works at: https://digitalcommons.library.umaine.edu/ers_facpub

Part of the Geomorphology Commons, Glaciology Commons, and the Hydrology Commons

\section{Repository Citation}

Mayewski, Paul Andrew and Jeschke, Peter A., "Himalayan and Trans-Himalayan Glacier Fluctuations Since AD 1812" (1979). Earth Science Faculty Scholarship. 185.

https://digitalcommons.library.umaine.edu/ers_facpub/185 


\title{
HIMALAYAN AND TRANS-HIMALAYAN GLACIER FLUCTUATIONS SINCE AD 1812
}

\author{
Paul A. Mayewski And Peter A. Jeschke \\ Department of Earth Sciences \\ University of New Hampshire \\ Durham, New Hampshire 03824
}

ABSTRACT

\begin{abstract}
Historical records of the fluctuations of glaciers in the Himalayas and Trans-Himalayas date back to the early 19 th century. Local and regional syntheses of 112 of these fluctuation records are presented in this study. The local syntheses deal with fluctuations of glaciers in Kanchenjunga-Everest, Garwhal, Lahaul-Spiti, Kolahoi, Nanga Parbat, Karakoram (north and south sides), RakaposhiHaramosh, Batura Mustagh, and KhunjerabGhujerab. Regional syntheses deal with the composite record and the differentiation of
\end{abstract}

records by glacier type (longitudinal versus transverse) and regional setting (Himalayan versus Trans-Himalayan). In a gross regional sense Himalayan and Trans-Himalayan glaciers have been in a general state of retreat since $A D$ 1850. Filtering of the fluctuation records with respect to glacier type and regional setting reveals that the period AD 1870 to 1940 was characterized by alternations in the dominancy of retreat, advance, and standstill regimes.

\section{INTRODUCTION}

The glaciers of high Asia comprise by area $50 \%$ of all glaciers outside of the polar regions, and they contain approximately 33 times the areal cover of the glaciers in the European Alps (Wissman, 1959). The vast glacier coverage included in two of the largest components of the high Asia glacier complex, the Himalayas and the Trans-Himalayas (Figure 1) is characterized by a regional firn limit that ranges in altitude from $5500-5600 \mathrm{~m}$ for Everest (Müller, 1958), to $5200-5700 \mathrm{~m}$ for the Garwhal (Grinlinton, 1914), to 4500$4700 \mathrm{~m}$ for Nanga Parbat (Finsterwalder, 1937), to $5000-5200 \mathrm{~m}$ for the south side of the Karakoram, and to $5500 \mathrm{~m}$ for the north side of the Karakoram (Visser and VisserHooft, 1938). Both the wide altitudinal range and the diverse orientations of the glaciers in 0004-0851/79/030267-21\$03.15 (C) 1979, Regents of the University of Colorado the Himalayas and the Trans-Himalayas (Fig ure 2) make these regions excellent sites for the study of glacier fluctuations.

Historical records of glacier fluctuations in the Himalayas and Trans-Himalayas extend back over 150 years. The earliest studies concerned with the movement of glacier termini were made for Chong Kumdan Glacier in AD 1812 (Izzet Ullah, 1842) and Milam Glacier (Hodgson, 1822). More modern references, cited by glacier in the Appendix, provide data on the fluctuation history of 112 glaciers. Several papers summarize the fluctuation record of subgroups of this total; notable amongst these are Mason (1930a), Visser and Visser-Hooft (1938), Mercer (1963), and Tewari (1971).

Mason (1930a), using historical records,

P. A. Mayewski And P. A. JeschKe / 267 


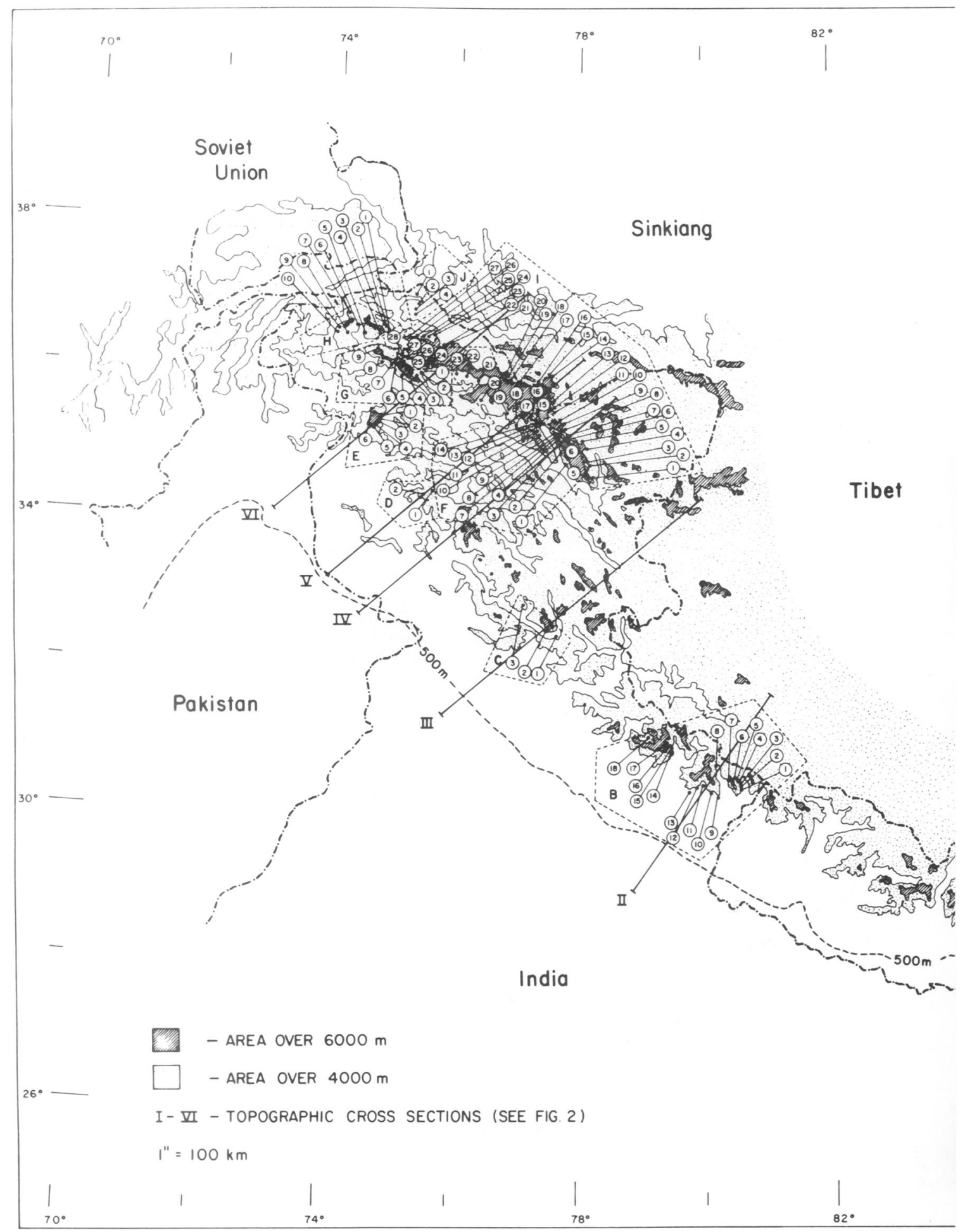

FIGURE 1. Glacier locations. 


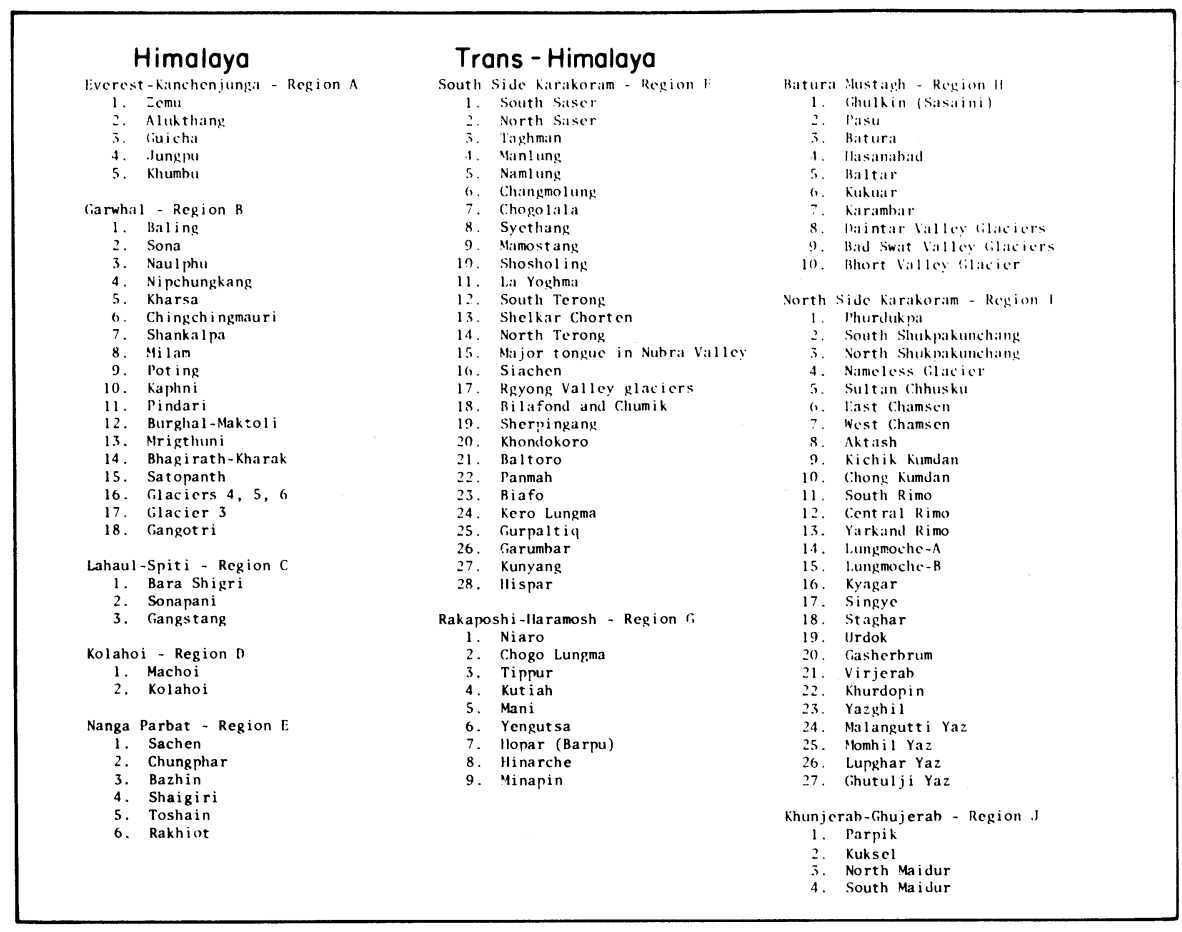

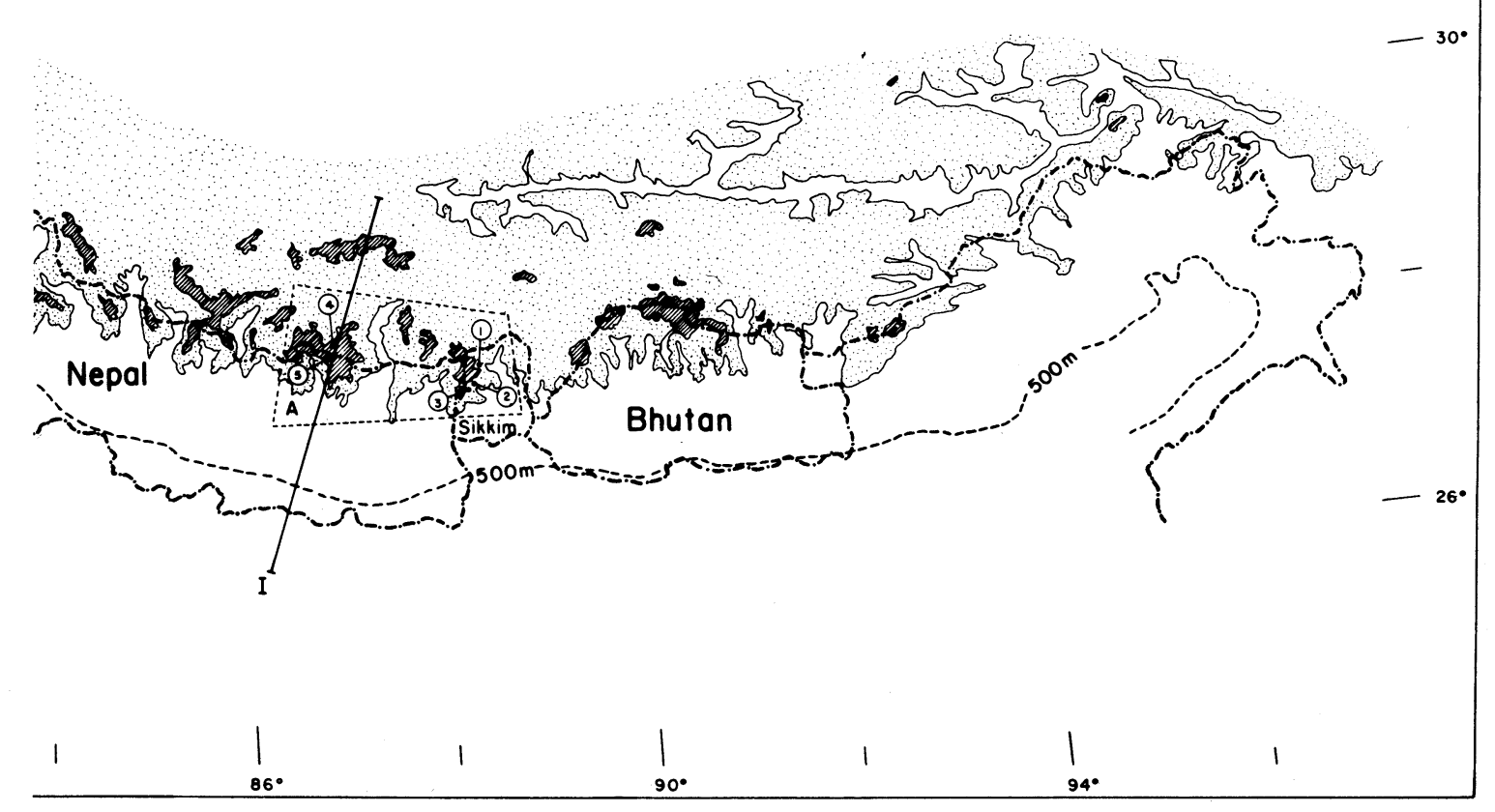




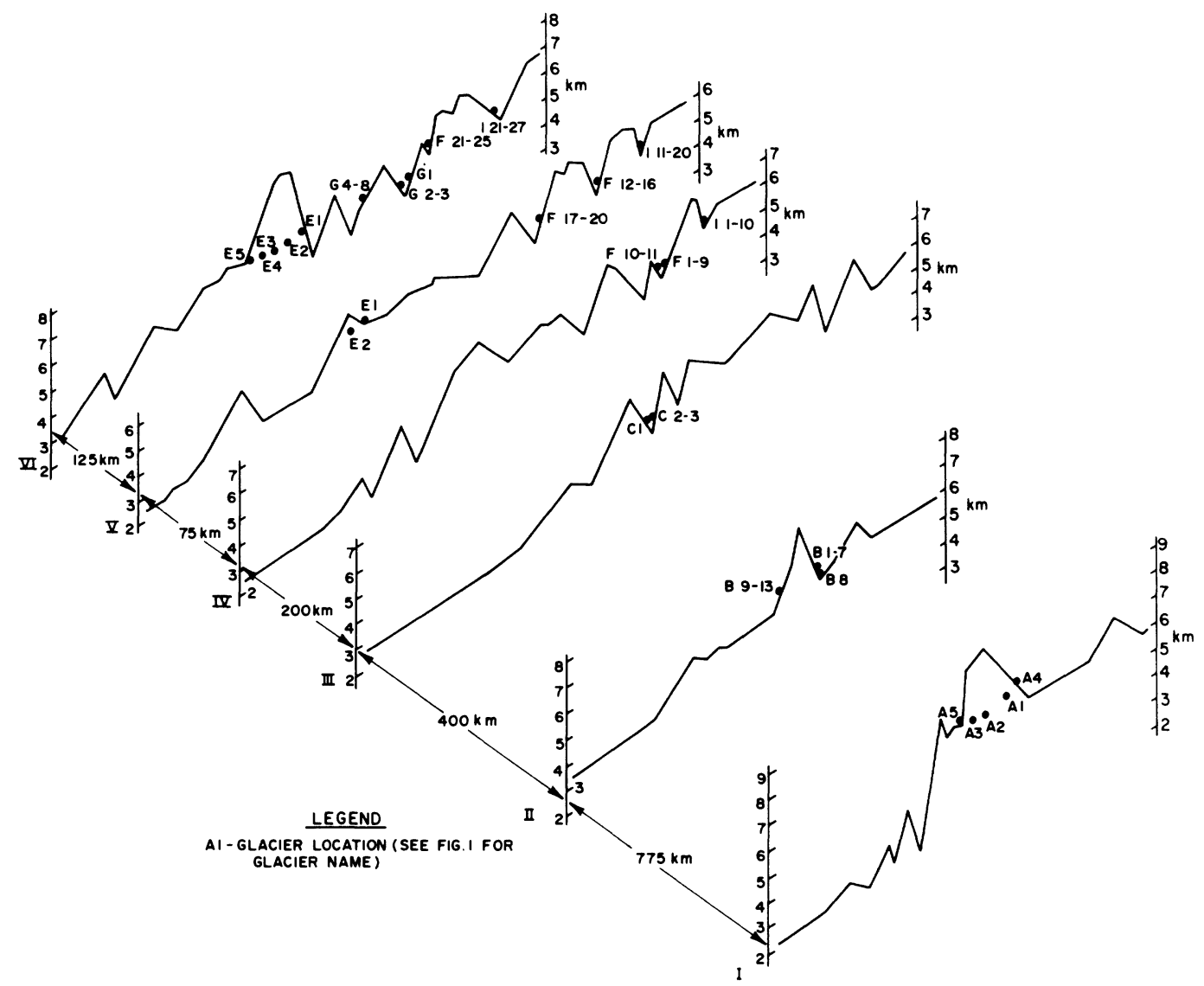

FIGURE 2. Cross sections displaying the altitudinal range and orientation of selected glaciers. Only portions of the cross sections above $2 \mathrm{~km}$ in elevation are shown.

notes, and photographs from his own and others' visits, documented the fluctuations of 34 glaciers in the Trans-Himalayas (Figure 1, $\mathrm{F}$ to J). Physical descriptions of all of these glaciers are included in his paper. Mason divided the glaciers in this area into two types-longitudinal and transverse-on the basis of their physical characteristics. Longitudinal glaciers flow generally in the wider east-west trending valleys of the range. These glaciers are relatively long and have relatively gentle surface slopes compared to the transverse glaciers. The transverse glaciers with their shorter length and steeper surface slopes flow perpendicular to the longitudinal type and therefore nearly perpendicular to the main axis of the range. Mason (1930a) summarized the fluctuation records of 21 of these glaciers and noted that several of the records displayed recognizable variations. These variations were categorized as secular (long term), periodic (short-term), seasonal, and accidental.

Visser and Visser-Hooft (1938, in Washburn, 1939) discussed fluctuations of 72 glaciers from the Trans-Himalayan region (Figure $1, F$ to $\mathrm{J}$ ). Most of their information is drawn from Mason (1926), Mason (1930a), or their own observations during expeditions to the Karakoram in the years AD 1922, 1925, 1929-1930, and 1935. Visser and Visser-Hooft plotted glacier fluctuations as a function of time for 61 glaciers, 32 of which had previously appeared in Mason (1930a). Their study also suggested that in the period $A D$ 1900 to 1910 most of the glaciers for which records were available were advancing, whereas in the period AD 1910 to 1920 the majority were retreating.

Mercer (1963) discussed the fluctuations of 
50 glaciers: 43 from the Trans-Himalayas (Figure 1, F to J) and 7 from the Nanga Parbat Massif (Figure 1, E). Thirty-one of these glaciers appeared in either Mason (1930a) or Visser and Visser-Hooft (1938). Mercer grouped them into three classes of advance: steady, cyclic or repeated, and catastrophic. Steady advances affected primarily the longer glaciers, especially from the early 19 th century until approximately $\mathrm{AD} 1920$, while the cyclic or repeated advances affected primarily shorter glaciers. The catastrophic advances documented are believed primarily to have been caused by earthquakes.
Tewari (1971) tabulated fluctuation data for 17 glaciers in the Himalayas and TransHimalayas and concluded that glaciers in the Himalayas, in general, were retreating while certain glaciers in the Trans-Himalayas displayed unexplained cyclic fluctuations.

The Himalayan and Trans-Himalayan fluctuations synthesized in this paper are presented as a reevaluation of the existing literature. Our work updates previous summaries and introduces an additional 27 glaciers for a total of 112 records of glacier fluctuations. Additional pertinent information concerning each glacier appears in the Appendix.

\section{LOCAL SYNTHESES}

The Himalayan and Trans-Himalayan records of glacier fluctuation used in our study (Figures 3-6) are arranged geographically according to the groupings delineated on Figure 1 . The records are displayed graphically in a fashion similar to the formats used by Mason (1930a) and Visser and Visser-Hooft (1938). Advances and retreats were determined from records of the movement of glacier termini. Due to a general absence and, in some cases, the unreliability of data concerning ice volume changes, such as downwasting and lateral spreading, the termini movements are used as the sole indication of advance or retreat. However, where icevolume changes were interpretable, descriptions appear on the graphs. An example is Khumbu Glacier, in the Everest-Kanchenjunga area (Figure 4) whose snout remained stationary from about AD 1930 to 1956 although the glacier thinned approximately $70 \mathrm{~m}$ under a thick debris cover during this period (Müller, 1958).

Summaries of the fluctuation records rely upon differing numbers of observations (plotted on Figures 3-6 as data points). Wherever possible interpolation between data points was made based upon conclusions drawn from published material. Conjectural connections between data points were so labelled based upon published material or, in a limited number of cases, our own interpretation of the data. In some cases single points, for example Mrigthuni Glacier in the Garwhal (Figure 3), have lines drawn through them indicating that the data point is part of a trend in advance or retreat. Some glaciers contain several data points from which more complex records can be interpreted, for example Pindari Glacier in the Garwhal (Figure 3). However, even in these cases shortterm advances or retreats may have been lost because of the spacing of the recording periods. Summaries of the fluctuation records for each of the 10 geographic areas in Figure 1 are presented below.

\section{KANCHENJUNGA-EVEREST}

Kanchenjunga-Everest glaciers (Figure 3) are commonly characterized by steep gradients, such as the vertical drop from 8500 to $4900 \mathrm{~m}$ over the $20-\mathrm{km}$ length of Khumbu Glacier. No Everest-Kanchenjunga glaciers extend below $4000 \mathrm{~m}$. Terminal portions of many of the glaciers in this region are heavily laden with debris. The relative stability of the snout positions held by Khumbu Glacier (Miller, 1965), Zemu Glacier (Bose et al., 1971), and Jungpu Glacier (Scientia, 1974), despite their recent thinning, has been ascribed to the insulating effect of this debris cover. This insulating effect is apparent even though each of these glaciers faces a different direction: Khumbu Glacier faces south, Zemu Glacier faces east, and Jungpu Glacier faces north.

\section{GARWHAL}

The Garwhal (Figure 3) contains some of the longest glaciers in the Himalayas; an example is Gangotri Glacier which is $30 \mathrm{~km}$ long. Several of the glaciers in this area descend to as low as $3600 \mathrm{~m}$. Garwhal glaciers for which records are available can be divided 

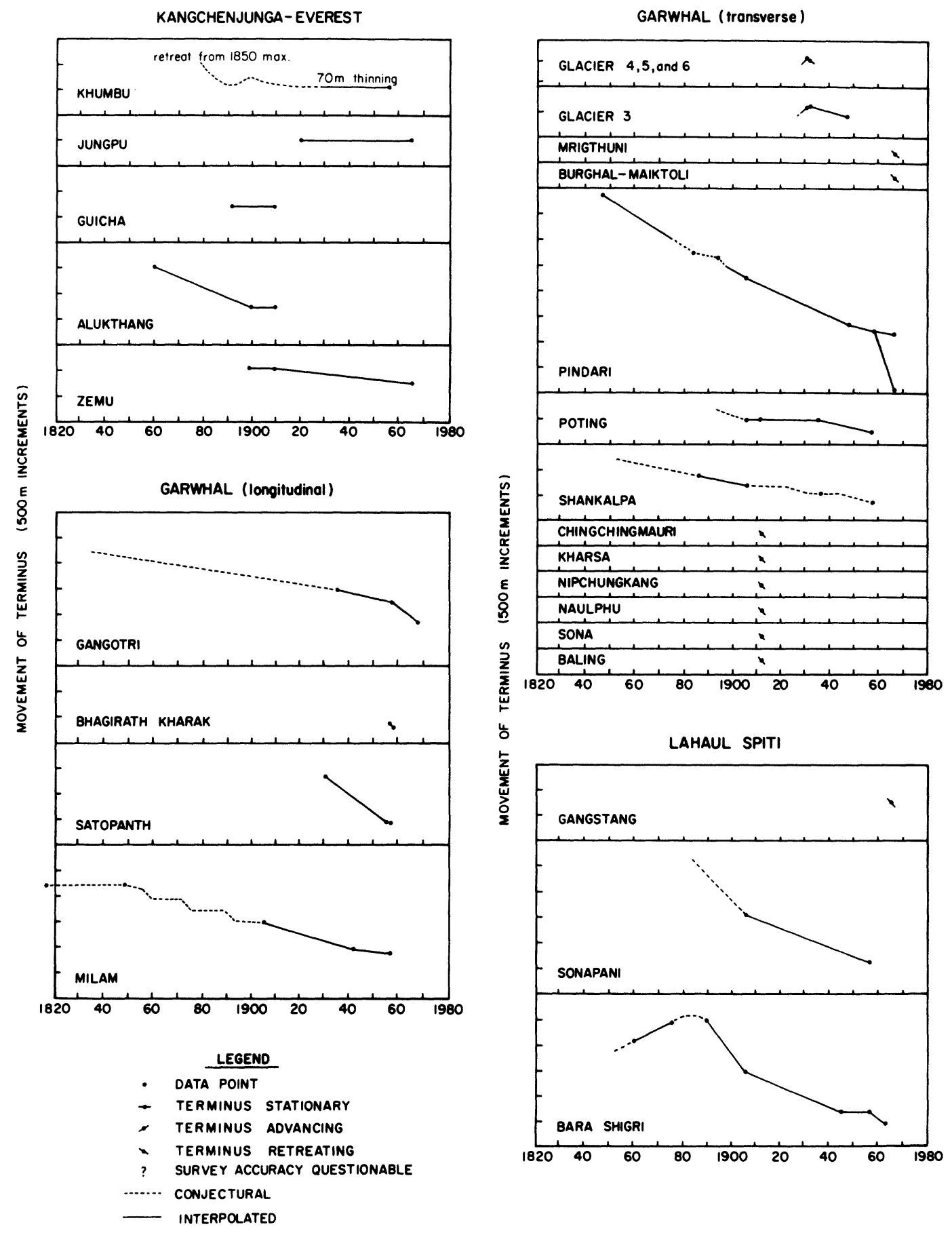

FIGURE 3. Kanchenjunga-Everest, Garwhal, and Lahaul-Spiti glacier fluctuations. 
into longitudinal and transverse types. Although the data are sparse it appears that glaciers in the Garwhal, regardless of type, have been in a state of retreat since AD 1850.

Pindari Glacier has undergone the greatest retreat of any glacier in the Himalayas. Total retreat of Pindari Glacier since AD 1850 has been $2600 \mathrm{~m}$. By AD 1958 retreat of this glacier caused it to split into two tributaries.

Milam Glacier is $20 \mathrm{~km}$ long and is the second longest glacier in the central Himalayas. This longitudinal glacier retreated $800 \mathrm{~m}$ from AD 1849 to 1906 (Cotter and Brown, 1907) and a further $620 \mathrm{~m}$ from AD 1906 to 1957 (Jangpangi, 1958). The lower $7 \mathrm{~km}$ is currently debris covered. The ridged lateral moraines and a series of end moraines indicate that retreat has not been steady.

\section{LAHAUL-SPITI}

Lahaul-Spiti glaciers (Figure 3) are located in the monsoon-arid transition zone (Krenek and Bhawan, 1945). Therefore, they may be considered to be potentially sensitive indicators of the northern limits and intensity of the monsoon. They are commonly covered by debris as indicated by the name Bara Shigri Glacier which means debris covered in the Spiti dialect (Dutt, 1961). Since their most recent maximum, approximately $\mathrm{AD} 1880$ to 1890 , the three glaciers of Lahaul-Spiti for which records exist have been receding.

Bara Shigri Glacier is a transverse glacier more than $10 \mathrm{~km}$ in length. This glacier advanced across the valley of the Chandra River damming a lake from AD 1860 to 1893 (Egerton, 1864). Retreat rates since this last maximum have been $62.5 \mathrm{~m} \mathrm{yr}^{-1}$ from $\mathrm{AD} 1890$ to $1906,20.5 \mathrm{~m} \mathrm{yr}^{-1}$ from AD 1906 to 1945 , and up to $28 \mathrm{~m} \mathrm{yr}^{-1}$ from $\mathrm{AD} 1956$ to 1963 (Walker and Pascoe, 1907; Krenek and Bhawan, 1945; Srikantia and Padhi, 1963).

\section{KOLAHOI}

Fluctuation records are available for only two glaciers in the Kolahoi. Of these two records the Kolahoi Glacier record is the longest. This glacier retreated $800 \mathrm{~m}$ from AD 1857 to 1909 and $800 \mathrm{~m}$ from AD 1912 to 1961 (Odell, 1963). A shorter record is available for Machoi Glacier. It advanced slightly around $\mathrm{AD} 1900$ and then retreated $457 \mathrm{~m}$ from AD 1906 to 1957 (Tewari, 1971).

\section{NANGA PARBAT}

The Nanga Parbat massif is characterized by extremely steep topography, vertical gradients are on the order of $300 \mathrm{~m} \mathrm{~km}^{-1}$. Glaciers in this massif (Figure 4), such as Chungphar Glacier, descend to elevations as low as $2800 \mathrm{~m}$.

Glaciers of Nanga Parbat have experienced a general, but rather minor, retreat (average $6 \mathrm{~m} \mathrm{yr}^{-1}$ ) since AD 1850. The only significant departures from this low retreat rate exist for Rakhiot and Chungphar glaciers which between $\mathrm{AD} 1930$ and 1950 had retreat rates as high as $30 \mathrm{~m} \mathrm{yr}^{-1}$. Despite this increase in retreat rate Rakhiot Glacier (Paffen et al., 1956) and Chungphar Glacier (Finsterwalder and Pillewizer, 1939) have been characterized by velocities that within the period AD 1930 to 1950 have been as much as two or more times pre-AD 1930 velocities.

\section{SOUTH SIDE OF KARAKORAM}

The south side of the Karakoram (Figures 4 and 5) contains some of the longest glaciers outside of the polar regions such as Siachen (75 km long) and Hispar (61 km long). Records from this area are available for both longitudinal and transverse glaciers although records for the former are far more complete. Several types of records are displayed by glaciers in this area (Mason, 1930a): (1) general recession since $A D 1880$ (Hispar) and even since AD 1850 (Baltoro), (2) fluctuation between advance and retreat in the period $\mathrm{AD}$ 1890 to 1930 (Biafo), and (3) catastrophic movements (Garumbar).

Hispar is a longitudinal glacier that forms the main trunk glacier for the local area. The névé field that feeds this glacier also feeds Biafo Glacier and several tributary glaciers. Documentation of the movement of the terminus of Hispar Glacier, summarized by Mason (1930a), suggests that this main trunk glacier has undergone a period of long-term recession which began no later than AD 1880 and, although decelerating in rate by approximately $\mathrm{AD} 1910$, is probably still continuing. Tributaries of this glacier display fluctuations of a shorter period that are, in fact, even "out of time" (Mason, 1930a: 227) with each other.

The greatest number and magnitude of fluctuations recorded for any glacier on the 

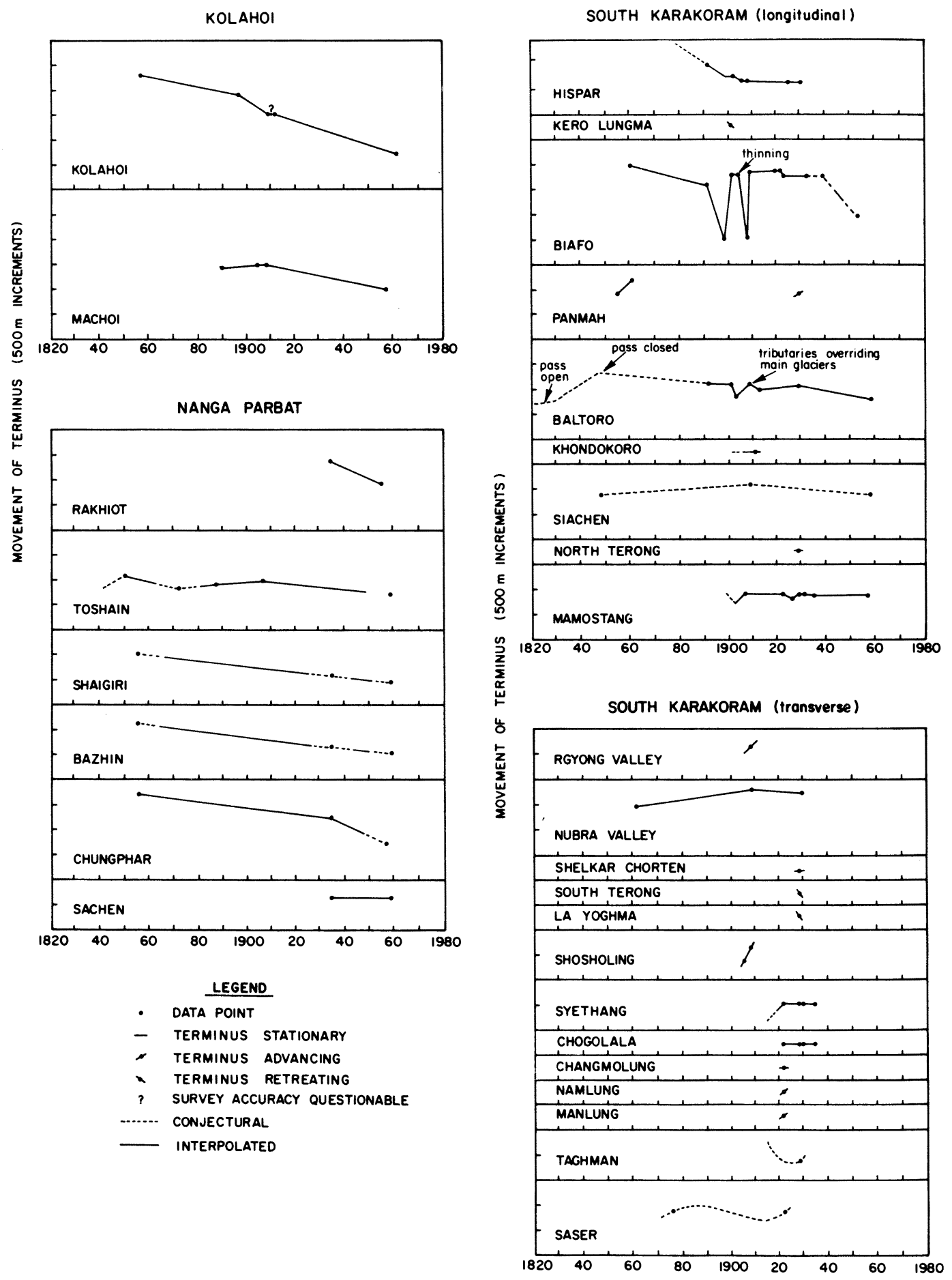

FIGURE 4. Kolahoi, Nanga Parbat, and South Karakoram glacier fluctuations. 
south side of the Karakoram are displayed by Biafo Glacier. Mason (1930a) suggests that fluctuation of this longitudinal glacier may be explained by the physical controls imposed by the glacier's drainage dimensions. It has a large $\left(64 \mathrm{~km}^{2}\right)$ snow basin that feeds a $4-\mathrm{km}$ wide valley that tapers within $10 \mathrm{~km}$ of the snout to a $1.5-\mathrm{km}$-wide valley. Mason (1930a) cautions that forward advance of Biafo Glacier could cause blockage of meltwater from Baltoro and other glaciers nearby.

The south side of the Karakoram may contain several surging glaciers, such as Garumbar, which may have experienced a $2.5-\mathrm{km}$ advance sometime between AD 1892 and 1925 (Mason, 1930a).

\section{RAKAPOSHI-HARAMOSH}

Rakaposhi-Haramosh glaciers (Figure 5) are divisible into longitudinal and transverse types. Glaciers in the area descend to an altitude of $2000 \mathrm{~m}$ and have been fluctuating between retreat and advance since at least $\mathrm{AD}$ 1850. In general, the $A D 1960$ margins of these glaciers are quite close to the AD 1850 positions. However, the $50 \mathrm{~km}$ long longitudinal Chogo Lungma Glacier reached its greatest post-AD 1300 maximum soon after AD 1912 (Kick, 1962).

Hewitt (1969) suggests that many of the glaciers of Rakaposhi-Haramosh have surged. Yengutz Glacier surged $3.2 \mathrm{~km}$ in $8 \mathrm{~d}$ during AD 1902/03 (Hayden, 1907), and Kutiah Glacier surged $12 \mathrm{~km}$ in 2 mon during $\mathrm{AD}$ 1953 (Desio, 1954). Minapin Glacier may also be a surging glacier (Mason, 1935).

\section{BatUra Mustagh}

Records for both longitudinal and transverse glaciers are available from the Batura Mustagh area. Fluctuations of Batura Mustagh glaciers (Figures 5 and 6) fall into two categories. The first includes those glaciers in the Baltar and Kukuar valleys. These valleys were free of ice in the early 19th century and by the late 19 th century contained glaciers at their maximum post-AD $1820 \mathrm{ex}$ tents. The second category includes glaciers in Daintar Valley and Pasu, Ghulkin, and Batura glaciers which reached their maximum during the early part of the 20th century.

Batura Mustagh contains some glaciers that have been known to surge, such as Hasanabad Glacier, which advanced $9.7 \mathrm{~km}$ in 2.5 mon during AD 1903 (Hayden, 1907). By AD 1954, Hasanabad Glacier had broken into several tributaries in response to the total 7-km retreat it experienced from AD 1892 to 1954 (Paffen et al., 1956).

\section{NORTH SIDE OF KARAKORAM}

Records for both longitudinal and trans verse glaciers are available from the north side of the Karakoram (Figure 6). In general, records of glacier fluctuations for this area are short, except for Chong Kumdan, Aktash, and Kichik Kumdan glaciers. Mason (1935) summarized the available data for these glaciers and concluded that periodic variations of 90 yr (Chong Kumdan), 55 yr (Aktash), and $35 \mathrm{yr}$ (Kichik Kumdan) within the time period AD 1830 to 1940 were differentiable for these glaciers. Tewari (1971) suggested cycles within the period AD 1812 to 1958 of 51 yr (Chong Kumdan), 55 yr (Aktash), and 45 yr (Kichik Kumdan). Mason (1930a) suggests that periodicity in the fluctuation record of Chong Kumdan Glacier, in particular, is due to its large snow basin reservoir which is capable, by means of outflow to the glacier, of exaggerating changes in snow input. All three glaciers have blocked the course of the Shyok River at several times, impounding large lakes (Mason, 1929). Subsequent bursting of these dams has caused a grave threat to the inhabitants below. In addition, Kichik Kumdan is believed to have surged $2.4 \mathrm{~km}$ in 7 mon during AD 1935/36 (Mason, 1940a).

\section{KHUNJERAB-GHUJERAB}

Glaciers of Khunjerab-Ghujerab (Figure 6) do not descend below $4000 \mathrm{~m}$. Records for the glaciers in this area only exist for AD 1925 (Mason, 1930a) and thus no interpretation can be made.

\section{REGIONAL SYNTHESIS}

Trends in the history of Himalayan and Trans-Himalayan glacier fluctuations are revealed in this study by reviewing the records of glacier fluctuations previously summarized as (1) a composite (112 glaciers), (2) groupings differentiated by glacier type (27 longi- 

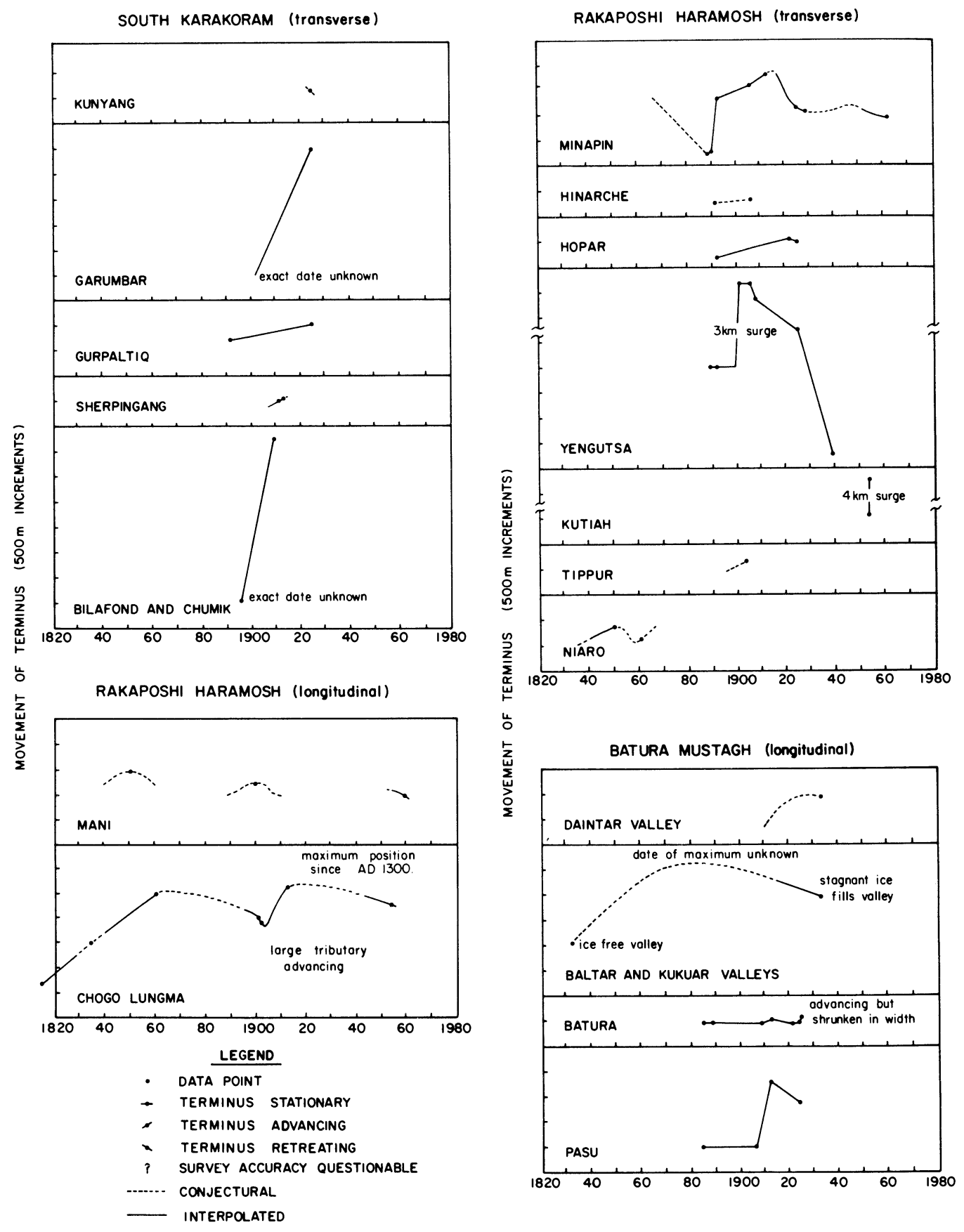

FIGURE 5. South Karakoram, Rakaposhi-Haramosh, and Batura Mustagh glacier fluctuations. 

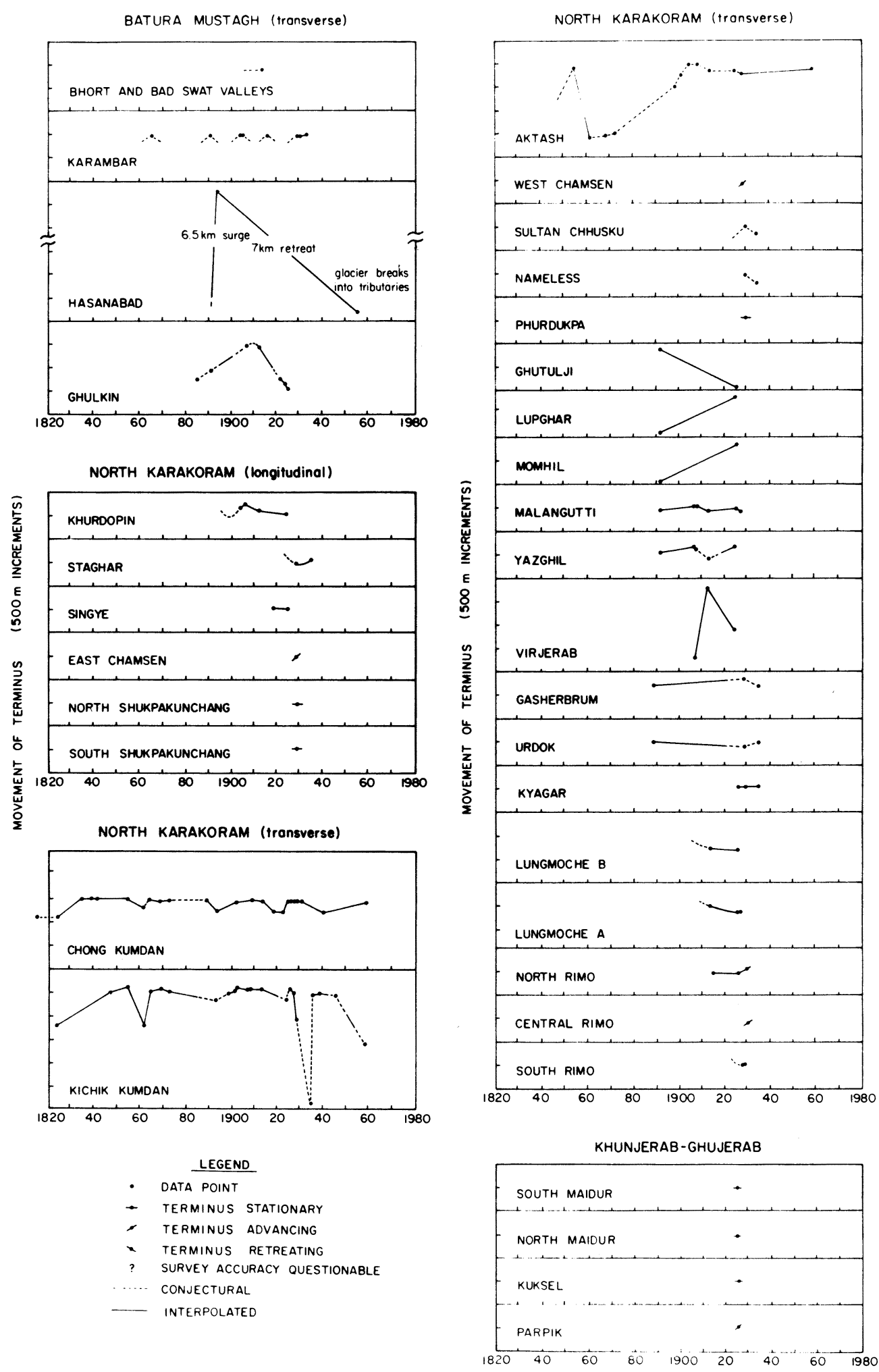

FIGURE 6. Batura Mustagh, North Karakoram, and Khunjerab-Ghujerab glacier fluctuations. 
tudinal and 68 transverse glaciers), and (3) groupings differentiated by regional setting (34 Himalayan and 74 Trans-Himalayan glaciers). Data used in this synthesis are presented in the form of frequency diagrams of glacier activity (Figure $7 \mathrm{a}-\mathrm{e}$ ) in which glacier activity is plotted for 10 -yr periods. The 10 -yr glacier activity trends fall into three cate- gories: advance, retreat, and standstill, each referring to the relative position of the terminus of the glacier. The data are presented as percentages to allow absolute comparison of 10 -yr periods despite differing numbers of observations per $10-\mathrm{yr}$ period. The total numbers of observations per 10 -yr period are also included in Figure 7 to prevent misinterpreta-
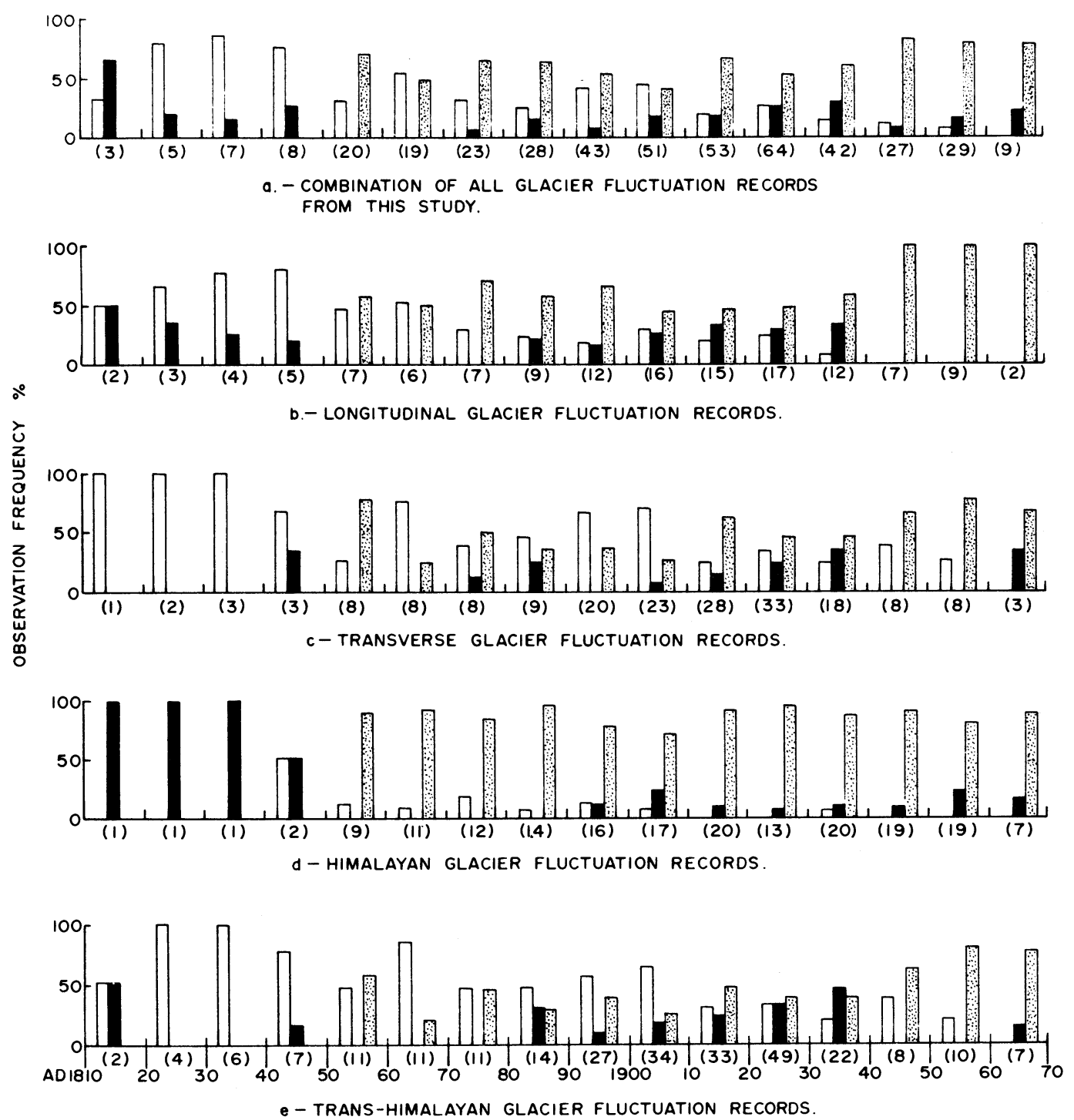

LEGEND

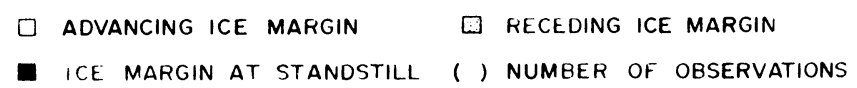

FIGURE 7. Glacier activity frequencies. 
tion of the percent frequency diagrams introduced by different sample populations per 10 yr period. In general, glacier observations have increased since AD 1850 with the peak in the observational period occurring from $\mathrm{AD}$ 1910 to 1930 . Records of surging glaciers have been excluded from Figure 7 because these glacier movements may be spurious and represent only a small fraction of the fluctuation record. In addition, records from glaciers prior to AD 1850 are also not included in this synthesis due to the sparsity of observations from $\mathrm{AD} 1810$ to 1850 . Results from Figure 7a-e follow.

Review of the composite record of all glacier fluctuations (Figure 7a) suggests that as a regional grouping the dominant regime since $\mathrm{AD} 1850$ has been retreat. However, the period AD 1870 to 1970 is characterized by several secondary trends in advance and standstill. In addition, when the number of advancing and stationary glacier termini are combined they exceed the number of retreating glacier termini during the period AD 1920 to 1940 , suggesting a near reversal in the dominance of the retreat regime for this period. Although review of the composite record yields a general impression of glacier regimes as a function of time, details in the record may be lost.

Analyses of the fluctuation of glaciers of different types and/or regional setting provide greater detail than that available from the composite record. A comparison of the records for longitudinal (Figure 7b) and transverse (Figure 7c) glaciers demonstrates that these physically different types of glaciers have different fluctuation histories. Longitudinal glaciers have been in a general state of retreat that began approximately $\mathrm{AD} 1850$. However, if advance and standstill records for longitudinal are combined, they dominate from AD 1900 to 1930 and provide a strong secondary regime from AD 1880 to 1900 and AD 1930 to 1940. Transverse glaciers retreated as a group from $\mathrm{AD} 1850$ to 1870 . Combined advance and standstill dominated transverse glaciers from AD 1870 to 1910 and from AD 1920 to 1930; retreat characterized the periods AD 1910 to 1920 and $\mathrm{AD} 1940$ to 1960 , and it probably continues today. Causes for the differences in the records of the two types of glaciers are only conjectural at this time, but we suggest that the apparently more complex record displayed by the transverse glacier group may be due to the fact that these glaciers are shorter, flow perpendicular to oncoming atmospheric circulation patterns, and have steeper gradients.

Fluctuation records of glaciers in the Himalayas (Figure 7d) differ from those of glaciers in the Trans-Himalayas (Figure 7e). Most glaciers in the Himalayas (KanchenjungaEverest, Lahaul-Spiti, Garwhal, Kolahoi, and Nanga Parbat) have been in a general state of retreat since AD 1850. Those in the TransHimalayan grouping (south side of the Karakoram, Rakaposhi-Haramosh, Batura Mustagh, and north side of the Karakoram) were either in retreat or advance from $A D$ 1850 to 1880 , reflected near-equivalent influences of retreat, standstill, and advance regimes from $\mathrm{AD} 1880$ to 1940 (combined standstill and advance records dominated), and have retreated since AD 1940. Tewari (1971), sampling a much smaller number of glaciers than the number sampled in this study, found similarly that the Himalayan glaciers were in a general state of retreat while the Trans-Himalayan glaciers have a more complicated record.

Glacier classifications other than the longitudinal and transverse types of Mason (1930a) have been suggested in the Himalayas and Trans-Himalayas. Visser and Visser-Hooft (1938, in Washburn, 1939) subdivided Karakoram glaciers into classes using the characteristics of their nourishment area (basinreservoir, plateau-reservoir, incised-reservoir, and avalanche types), whereas Pillewizer (1958) subdivided Himalayan and Karakoram glaciers into classes on the basis of their type of movement (block and flow types). Comparison of records of glacier fluctuations implementing these and other types of classifications may prove to be as informative as the longitudinal/transverse and the Himalayan/Trans-Himalayan comparison.

\section{ACKNOWLEDGMENTS}

We wish to thank Dr. John Hollin for his extremely useful review of our paper and his helpful suggestions. Warren Celli, University of New Hampshire, drafted all of the figures 
used in the paper and was instrumental in their design. Pamela Brown and Eric Vogl, both of University of New Hampshire, translated into English the German texts used in the paper. University of New Hampshire CURF Grant 694 provided the funds necessary for the preparation of this paper.

\section{APPENDIX}

\section{Glacier Data}

\begin{tabular}{|c|c|c|c|c|c|c|c|}
\hline Glacier name & $\begin{array}{c}\text { Location index } \\
\text { (see Figure 1) }\end{array}$ & Type & $\begin{array}{c}\text { Length } \\
(\mathrm{km})\end{array}$ & Exposure & $\begin{array}{c}\text { Snout } \\
\text { elev. } \\
(\mathrm{m})\end{array}$ & $\begin{array}{r}\text { Last date } \\
\text { examined }\end{array}$ & References \\
\hline \multicolumn{8}{|c|}{ Everest-Kanchenjunga (Region A) } \\
\hline Zemu & 1 & - & 25 & E & 4000 & 1965 & $\begin{array}{l}9,28,29,50 \\
66,79,96\end{array}$ \\
\hline Alukthang & 2 & - & - & $\mathrm{S}$ & 4000 & 1909 & $6,28,29,66,79$ \\
\hline Guicha & 3 & - & - & $\mathrm{SE}$ & - & 1909 & 66,79 \\
\hline Jungpu & 4 & - & - & $\mathrm{N}$ & $>4000$ & 1968 & 102 \\
\hline Khumbu & 5 & - & 20 & $\mathrm{~S}$ & 4900 & 1963 & $\begin{array}{l}8,57,74,79,80 \\
81,82,84,125\end{array}$ \\
\hline \multicolumn{8}{|c|}{ Garwhal (Region B) } \\
\hline Baling & 1 & TR & 5 & NE & 3250 & 1912 & $37,38,39$ \\
\hline Sona & 2 & $\mathrm{TR}$ & 6 & NE & 3380 & 1912 & $37,38,79$ \\
\hline Naulphu & 3 & TR & 6 & $\mathrm{NE}$ & 4000 & 1912 & 38,79 \\
\hline Nipchungkang & 4 & $\mathrm{TR}$ & 6 & $\mathrm{NE}$ & 3860 & 1912 & 38,79 \\
\hline Kharsa & 5 & $\mathrm{TR}$ & 6 & $\mathrm{NE}$ & 3810 & 1912 & 38,79 \\
\hline Chingchingmauri & 6 & TR & 6 & $\mathrm{NE}$ & 4170 & 1912 & 38,79 \\
\hline Shankalpa & 7 & $\mathrm{TR}$ & 13 & $\mathrm{SE}$ & 4300 & 1957 & $\begin{array}{l}14,29,43,44 \\
54,55,79,115\end{array}$ \\
\hline Milam & 8 & $\mathrm{~L}$ & 20 & SW & 3390 & 1962 & $\begin{array}{l}1,14,29,43,44 \\
49,54,79,108 \\
109,110,115\end{array}$ \\
\hline Poting & 9 & TR & 5 & SW & 3650 & 1957 & $\begin{array}{l}14,29,37,54 \\
79,115\end{array}$ \\
\hline Kaphni & 10 & TR & 3 & $\mathrm{~S}$ & 3800 & 1958 & $108,115,118$ \\
\hline Pindari & 11 & $\mathrm{TR}$ & 5 & SW & 3650 & 1966 & $\begin{array}{l}3,10,14,29 \\
54,79,83,98 \\
108,111,115 \\
116,117\end{array}$ \\
\hline Burghal-Maiktoli & 12 & TR & 4 & S & - & 1966 & 112 \\
\hline Mrigthuni & 13 & TR & 8 & $\mathrm{~S}$ & - & 1966 & 113 \\
\hline Bhagirath-Kharak & 14 & $\mathrm{~L}$ & 18 & $\mathrm{E}$ & 3650 & 1959 & $54,79,94,115$ \\
\hline Satopanth & 15 & $\mathrm{~L}$ & 16 & $\mathrm{NE}$ & 3800 & 1959 & $\begin{array}{l}54,79,104 \\
108,115\end{array}$ \\
\hline Glacier IV, V, VI & 16 & TR & $2-3$ & $\mathrm{~N}$ & 4200 & 1932 & 7,31 \\
\hline Glacier III & 17 & TR & $2 \cdot 3$ & $\mathrm{~N}$ & 4200 & 1957 & $7,31,54,79,115$ \\
\hline Gangotri & 18 & $\mathrm{~L}$ & 30 & NW & 3880 & 1967 & $\begin{array}{l}5,36,54,79 \\
114,115,127 \\
\end{array}$ \\
\hline \multicolumn{8}{|c|}{ Lahaul-Spiti (Region C) } \\
\hline Bara Shigri & 1 & TR & $>10$ & $\mathrm{~N}$ & 4080 & 1963 & $\begin{array}{l}21,22,29,30,40 \\
64,70,79,105 \\
115,126,130\end{array}$ \\
\hline
\end{tabular}




\begin{tabular}{|c|c|c|c|c|c|c|c|}
\hline Glacier name & $\begin{array}{c}\text { Location index } \\
\text { (see Figure } 1 \text { ) }\end{array}$ & Type & $\begin{array}{l}\text { Length } \\
(\mathrm{km})\end{array}$ & Exposure & $\begin{array}{l}\text { Snout } \\
\text { elev. } \\
\text { (m) }\end{array}$ & $\begin{array}{l}\text { Last date } \\
\text { examined }\end{array}$ & References \\
\hline Sonapani & 2 & TR & 15 & $\mathrm{SE}$ & 3856 & 1957 & $\begin{array}{l}29,40,65,79 \\
115,126\end{array}$ \\
\hline Gangstang & 3 & $\mathrm{TR}$ & 6 & SE & 4420 & 1963 & $11,79,85$ \\
\hline \multicolumn{8}{|c|}{ Kolahoi (Region D) } \\
\hline Machoi & 1 & TR & 3 & $\mathbf{N}$ & 3733 & 1957 & $86,89,95,115$ \\
\hline Kolahoi & 2 & TR & 5 & NW & 3660 & 1973(?) & $2,29,79,86,87$ \\
\hline \multicolumn{8}{|c|}{ Nanga Parbat (Region E) } \\
\hline Sachen & 1 & - & 6 & $\mathrm{E}$ & 3350 & 1958 & $\begin{array}{l}25,60,67,77 \\
79\end{array}$ \\
\hline Chungphar & 2 & - & 8 & SE & 2850 & 1958 & $\begin{array}{l}25,60,67,77 \\
79\end{array}$ \\
\hline Bazhin & 3 & - & 7 & SE & 3250 & 1958 & $\begin{array}{l}25,60,67,77 \\
79\end{array}$ \\
\hline Shaigiri & 4 & - & 6 & S-SE & 3600 & 1958 & $\begin{array}{l}25,60,67,77 \\
79\end{array}$ \\
\hline Toshain & 5 & - & 7 & SE & 3700 & 1958 & $\begin{array}{l}24,25,60,67 \\
77,79\end{array}$ \\
\hline Rakhiot & 6 & - & 12 & $\mathrm{~N}$ & 3160 & 1954 & $\begin{array}{l}27,59,77,79 \\
92,93\end{array}$ \\
\hline \multicolumn{8}{|c|}{ South Side of the Karakoram (Region F) } \\
\hline South Saser & 1 & $\mathrm{TR}$ & 11 & $\mathrm{~W}$ & 4850 & 1922 & $33,77,78,124$ \\
\hline North Saser & 2 & $\mathrm{TR}$ & 6 & SE & 4800 & 1922 & $33,77,78,124$ \\
\hline Taghman & 3 & $\mathrm{TR}$ & 6 & NW & 4725 & 1929 & 124 \\
\hline Manlung & 4 & TR & 9 & $\mathrm{~W}$ & 5000 & 1922 & 124 \\
\hline Namlung & 5 & $\mathrm{TR}$ & 3 & $\mathrm{~W}$ & - & 1922 & 78,124 \\
\hline Changmolung & 6 & $\mathrm{TR}$ & 7 & NW & 5200 & 1922 & 78,124 \\
\hline Chogolala & 7 & $\mathrm{TR}$ & 3 & $\mathrm{~N}$ & 4850 & 1922 & 78,124 \\
\hline Syethang & 8 & TR & 6 & $\mathrm{~N}$ & 4900 & 1922 & 78,124 \\
\hline Mamostang & 9 & $\mathrm{~L}$ & 16 & $\mathrm{~S}$ & 4400 & 1935 & $78,115,124$ \\
\hline Shosholing & 10 & $\mathrm{TR}$ & $5(?)$ & $\mathrm{E}$ & - & 1909 & 68,77 \\
\hline La Yoghma & 11 & TR & 15 & NE & 4000 & 1929 & 124 \\
\hline South Terong & 12 & $\mathrm{TR}$ & 21 & NW & 4050 & 1929 & 78,124 \\
\hline Shelkar Chorten & 13 & TR & 21 & $\mathrm{~W}$ & - & 1929 & 78,124 \\
\hline North Terong & 14 & $\mathrm{~L}$ & 25 & $\mathrm{~S}$ & 3960 & 1929 & 78,124 \\
\hline $\begin{array}{l}\text { Major Tongue in } \\
\text { Nubra Valley }\end{array}$ & 15 & - & - & - & - & 1929 & 124 \\
\hline Siachen & 16 & $\mathrm{~L}$ & 75 & $\mathrm{SE}$ & 3705 & 1958 & $\begin{array}{l}16,51,68,77 \\
78,115,120 \\
137\end{array}$ \\
\hline Rgyong Valley & 17 & TR & 18 & $\mathrm{~W}$ & 4000 & 1909 & $68,77,78,124$ \\
\hline Bilafond and Chumik & 18 & TR & 23 & $\mathrm{~S}$ & 3800 & 1912 & $\begin{array}{l}68,77,78 \\
124,137\end{array}$ \\
\hline Sherpingang & 19 & TR & $15(?)$ & SW & - & 1913 & $18,77,78,137$ \\
\hline Khondokoro & 20 & $\mathrm{~L}$ & $18(?)$ & $\mathrm{S}$ & - & 1911 & $77,78,137$ \\
\hline Baltoro & 21 & $\mathrm{~L}$ & 58 & W & 3530 & 1958 & $\begin{array}{l}13,17,18,27 \\
32,73,77,78 \\
91,124\end{array}$ \\
\hline Panmah & 22 & $\mathrm{TR}$ & 27 & $\mathrm{~S}$ & 3625 & 1929 & $\begin{array}{l}19,32,73,77 \\
124\end{array}$ \\
\hline Biafo & 23 & $\mathrm{~L}$ & 59 & $\mathrm{SE}$ & 3160 & 1953 & $\begin{array}{l}4,13,17,23 \\
32,46,62,73 \\
77,78,91 \\
124\end{array}$ \\
\hline
\end{tabular}




\begin{tabular}{|c|c|c|c|c|c|c|c|}
\hline Glacier name & $\begin{array}{c}\text { Location index } \\
\text { (see Figure 1) }\end{array}$ & Type & $\begin{array}{c}\text { Length } \\
(\mathrm{km})\end{array}$ & Exposure & $\begin{array}{l}\text { Snout } \\
\text { elev. } \\
\text { (m) }\end{array}$ & $\begin{array}{l}\text { Last date } \\
\text { examined }\end{array}$ & References \\
\hline Kero Lungma & 24 & $\mathrm{~L}$ & 19 & $\mathrm{E}$ & 3600 & 1902 & 63,124 \\
\hline Gurpaltiq & 25 & TR & 4 & $\mathrm{~N}$ & 3320 & 1925 & $13,121,124$ \\
\hline Garumbar & 26 & $\mathrm{TR}$ & 8 & $\mathrm{~N}$ & 3230 & 1925 & $\begin{array}{l}13,47,75,77 \\
121,124\end{array}$ \\
\hline Kunyang & 27 & TR & 24 & $\mathrm{~S}$ & 3450 & 1925 & 121,124 \\
\hline Hispar & 28 & $\mathrm{~L}$ & 62 & W & 3000 & 1930 & $\begin{array}{l}13,29,41,73, \\
77,121,124, \\
133,135\end{array}$ \\
\hline \multicolumn{8}{|c|}{ Rakaposhi-Haramosh (Region G) } \\
\hline Niaro & 1 & TR & 6 & $\mathrm{NE}$ & - & 1861 & 32,77 \\
\hline Chogo Lungma & 2 & $\mathrm{~L}$ & 50 & $\mathrm{E}$ & 2075 & 1954 & $\begin{array}{l}18,32,58,60, \\
61,73,77,78, \\
88,120,124, \\
134,136\end{array}$ \\
\hline Tippur & 3 & TR & 7 & $\mathrm{~N}$ & 2900 & 1929 & $\begin{array}{l}77,78,124 \\
134\end{array}$ \\
\hline Kutiah & 4 & TR & 12 & $\mathrm{~S}$ & - & 1953 & $20,47,77$ \\
\hline Mani & 5 & $\mathrm{~L}$ & 10 & NW & - & 1958 & 77,129 \\
\hline Yengutsa & 6 & TR & 11 & $\mathrm{~N}$ & 3250 & 1939 & $\begin{array}{l}13,29,41,47 \\
73,77,78 \\
124,133\end{array}$ \\
\hline Hopar & 7 & TR & 21 & $\mathrm{~N}$ & 2300 & 1925 & $\begin{array}{l}13,47,73,77 \\
120\end{array}$ \\
\hline Hinarche & 8 & TR & 6 & $\mathrm{~S}$ & - & 1907 & $\begin{array}{l}13,29,41 \\
77,78\end{array}$ \\
\hline Minapin & 9 & TR & 16 & $\mathrm{~N}$ & 2200 & 1961 & $\begin{array}{l}12,13,29,41 \\
47,71,73,77 \\
79,99,124\end{array}$ \\
\hline
\end{tabular}

\begin{tabular}{|c|c|c|c|c|c|c|c|}
\hline \multicolumn{8}{|c|}{ Batura Mustagh (Region $\mathrm{H}$ ) } \\
\hline Ghulkin & 1 & $\mathrm{~L}$ & 18 & $\mathrm{E}$ & 2440 & 1925 & $73,78,121,124$ \\
\hline Pasu & 2 & $\mathrm{~L}$ & 25 & $\mathrm{E}$ & 2550 & 1925 & $73,78,121,124$ \\
\hline Batura & 3 & $\mathbf{L}$ & 58 & $\mathrm{E}$ & 2460 & 1925 & $\begin{array}{l}63,73,77,78 \\
124\end{array}$ \\
\hline Hasanabad & 4 & TR & 20 & $\mathrm{~S}$ & 2225 & 1954 & $\begin{array}{l}41,73,77,78 \\
90,124\end{array}$ \\
\hline Baltar & 5 & $\mathrm{~L}$ & 12 & W & $3000 \pm$ & 1933 & $77,78,101$ \\
\hline Kukuar & 6 & $\mathbf{L}$ & 18 & $\mathrm{~S}$ & $3000 \pm$ & 1933 & $77,78,101$ \\
\hline Karambar & 7 & TR & 25 & W & $3000 \pm$ & 1933 & $\begin{array}{l}48,75,77 \\
78,100\end{array}$ \\
\hline Daintar Valley & 8 & $\mathrm{~L}$ & 12 & $\mathrm{SE}$ & $3000 \pm$ & 1933 & $77,78,101$ \\
\hline Bad Swat Valley & 9 & TR & 5 & W & $3000 \pm$ & 1933 & $77,78,100$ \\
\hline Bhort Valley & 10 & TR & 10 & W & $3000 \pm$ & 1933 & $77,78,100$ \\
\hline \multicolumn{8}{|c|}{ North Side of the Karakoram (Region I) } \\
\hline Purdukpa & 1 & TR & 18 & $\mathrm{E}$ & 4900 & 1935 & 124 \\
\hline So. Shukpakunchang & 2 & $\mathrm{~L}$ & 27 & $\mathrm{SE}$ & 4640 & 1930 & 124 \\
\hline No. Shukpakunchang & 3 & $\mathrm{~L}$ & 25 & $\mathrm{E}$ & 4560 & 1930 & 124 \\
\hline Nameless & 4 & TR & 7 & $\mathrm{E}$ & 4900 & 1935 & 124 \\
\hline Sultan Chhusku & 5 & $\mathrm{TR}$ & 14 & $\mathrm{NE}$ & 4300 & 1935 & $47,77,124$ \\
\hline East Chamsen & 6 & $\mathrm{~L}$ & 11 & $\mathrm{~N}$ & 4700 & 1929 & 122,124 \\
\hline
\end{tabular}




\begin{tabular}{|c|c|c|c|c|c|c|c|}
\hline Glacier name & $\begin{array}{c}\text { Location index } \\
\text { (see Figure 1) }\end{array}$ & Type & $\begin{array}{c}\text { Length } \\
(\mathrm{km})\end{array}$ & Exposure & $\begin{array}{l}\text { Snout } \\
\text { elev. } \\
(\mathrm{m})\end{array}$ & $\begin{array}{l}\text { Last date } \\
\text { examined }\end{array}$ & References \\
\hline West Chamsen & 7 & TR & 15 & $\mathrm{NE}$ & 4700 & 1929 & 122,124 \\
\hline Aktash & 8 & TR & 8 & $\mathrm{E}$ & 4575 & 1958 & $\begin{array}{l}33,34,42,43 \\
51,68,69,72 \\
73,74,75,77 \\
103,115,132\end{array}$ \\
\hline Kickik Kumdan & 9 & TR & 11 & $\mathrm{E}$ & 4635 & 1958 & $\begin{array}{l}26,33,34,35, \\
39,42,45,47, \\
51,68,69,73, \\
74,75,76,77, \\
78,97,103, \\
106,107,115, \\
119,124,132\end{array}$ \\
\hline Chong Kumdan & 10 & TR & 21 & $\mathrm{E}$ & 4715 & 1958 & $\begin{array}{l}18,26,33,34, \\
35,47,51,52, \\
53,56,68,69, \\
72,73,74,75, \\
78,97,103, \\
107,115,120, \\
124,132\end{array}$ \\
\hline South Rimo. & 11 & $\mathrm{TR}$ & 24 & $\mathrm{E}$ & 4825 & 1935 & $\begin{array}{l}15,73,77,78 \\
124,132\end{array}$ \\
\hline Center Rimo & 12 & TR & 40 & $\mathrm{E}$ & 5000 & 1935 & $\begin{array}{l}15,73,77,78 \\
124,132\end{array}$ \\
\hline Rimo-Yarkand & 13 & & 20 & $\mathrm{NE}$ & 5213 & 1932 & $15,73,77,78$ \\
\hline Lungmoche-A & 14 & TR & 11 & NW & 5025 & 1926 & $\begin{array}{l}73,78,124, \\
132\end{array}$ \\
\hline Lungmoche-B & 15 & TR & 15 & NW & 5030 & 1926 & $\begin{array}{l}73,78,124, \\
132\end{array}$ \\
\hline Kyagar & 16 & TR & 22 & $\mathrm{~N}$ & 4775 & 1935 & $\begin{array}{l}19,73,78 \\
124\end{array}$ \\
\hline Singye & 17 & -TR & 24 & NW & 4575 & 1935 & $19,78,124$ \\
\hline Staghar & 18 & -TR & 18 & NW & 4425 & 1935 & $19,78,124$ \\
\hline Urdok & 19 & $\mathrm{TR}$ & 23 & NW & 4365 & 1935 & $\begin{array}{l}19,78,124, \\
138\end{array}$ \\
\hline Gasherbrum & 20 & TR & 21 & $\mathrm{NE}$ & 4345 & 1935 & $\begin{array}{l}19,78,124 \\
138\end{array}$ \\
\hline Virjerab & 21 & TR & 40 & NW & 3450 & 1925 & $\begin{array}{l}73,78,121 \\
124\end{array}$ \\
\hline Khurdopin & 22 & $-\mathrm{TR}$ & 47 & NW & 3250 & 1925 & $\begin{array}{l}73,77,78 \\
121,123,124\end{array}$ \\
\hline Yazghil & 23 & $\mathrm{TR}$ & 31 & $\mathrm{~N}$ & 3190 & 1925 & $\begin{array}{l}73,77,78 \\
121,124\end{array}$ \\
\hline Malangutti Yaz & 24 & $\mathrm{TR}$ & 23 & $\mathrm{~N}$ & 2900 & 1925 & $\begin{array}{l}73,77,78, \\
121,124\end{array}$ \\
\hline Momhil Yaz & 25 & $\mathrm{TR}$ & 32 & $\mathbf{N}$ & 2900 & 1925 & $73,121,124$ \\
\hline Lupghar Yaz & 26 & TR & 12 & $\mathrm{~N}$ & 3050 & 1925 & 73,124 \\
\hline Ghutulji Yaz & 27 & TR & 13 & $\mathrm{~N}$ & 3350 & 1925 & 73,124 \\
\hline
\end{tabular}

\begin{tabular}{lccccccc}
\hline \multicolumn{10}{c}{ Khunjerab-Ghujerab (Region J) } \\
\hline Parpik & 1 & TR & 14 & W & 4360 & 1925 & $73,77,78$, \\
Kuksel & 2 & TR & 7 & E & 4600 & 1925 & 73,124
\end{tabular}




\begin{tabular}{|c|c|c|c|c|c|c|c|}
\hline Glacier name & $\begin{array}{c}\text { Location index } \\
\text { (see Figure 1) }\end{array}$ & Type & $\begin{array}{l}\text { Length } \\
(\mathrm{km})\end{array}$ & Exposure & $\begin{array}{l}\text { Snout } \\
\text { elev. } \\
(\mathrm{m})\end{array}$ & $\begin{array}{l}\text { Last date } \\
\text { examined }\end{array}$ & References \\
\hline North Maidur & 3 & $\mathrm{TR}$ & 10 & $\mathrm{~N}$ & 4550 & 1925 & 73,124 \\
\hline South Maidur & 4 & $\mathrm{TR}$ & 3 & $\mathrm{~S}$ & 4800 & 1925 & 73,124 \\
\hline
\end{tabular}

\section{REFERENCES CITÉD}

1. Ahmad, N., 1962: Milam Glacier, Kumaun Himalaya. In: Variations of the Regime of Existing Glaciers: Symposium of Obergurgl, 10 September-18 September 1962. Commission of Snow and Ice, Int. Assoc. Sci. Hydrol. Publ., 58: 230-233.

2. Ahmad, N. and Hashimi, N. H., 1974: Glacial history of Kolahoi Glacier, Kashmir, India.J. Glaciol., 13: 279-283.

3. Ahmad, N. and Saxena, H. B., 1963: Glaciations of the Pindar Valley, Southern Himalayas. J. Glaciol., 4: 471-476.

4. Auden, J. B., 1935: The snout of the Biafo Glacier in Baltistan. Rec. Geol. Surv. India, 68(4): 400-413.

5. _- 1937: The snout of the Gangotri Glacier, Tehri Garwhal. Rec. Geol. Surv. India, 72(2): 135-140.

6. Bellew, H. W., 1875: Kashmir and Kashgar. London: Trübner and Co. $419 \mathrm{pp}$.

7. Birnie, Capt., 1932: Arwa Valley glaciers. Himalayan J., 4: 35-45.

8. Bishop, B. C., 1970: Scientific research in the high Himalayas. In: Research Reports 1961-1962. Washington, D. C.: National Geographic Society, 27-39.

9. Bose, R. N., Dutta, N. P., and Lahiri, S. M., 1971: Refraction seismic investigation at Zemu Glacier, Sikkim. J. Glaciol., 10: 113-119.

10. Bose, S. C., 1970: Recent recession in Himalayan glaciers. Int. Geogr. Congr., Comm. 21: 14-17.

11. Bose, S. C. et al., 1960: Expedition to Gangstang Glacier. Geogr. Rev. India, 22(3): 4952.

12. Cambridge Expedition to Nagir, Karakoram, 1961: General Report, 1961. Cambridge: Cambridge University.

13. Conway, W. M., 1894: Climbing in the Himalayas. London: T. Fisher Unwin. 3 vol.

14. Cotter, G. de P. and Brown, J., 1907: Notes on certain glaciers in Kumaon. Rec. Geol. Surv. India, 35: 148-157.

$1 \rightarrow$ Dainelli, G., 1932: Italia Pass in the Eastern Karakoram. Geogr. Rev., 22: 392-402.

16. —_, 1934: Buddhists and Glaciers of Western Tibet. New York: E. P. Dutton.
$304 \mathrm{pp}$.

17. De Filippi, F., 1912: Karakoram and Western Himalaya, 1909. London: Edward Arnold. 469 pp.

18. - 1932: The Italian Expedition to the Himalaya, Karakoram, and Eastern Turkestan (1913-1914). London: Edward Arnold.

$1 \rightarrow$ Desio, A., 1930: Geological work of the Italian expedition to the Karakoram. Geogr.J., 75: 402-411.

20. - 1954: An exceptional glacier advance in the Karakoram-Ladakh Region. J. Glaciol., 2: 383-385.

21. Dutt, G. N., 1961: The Bara Shigri Glacier, Kangra District, East Punjab, India. J. Gla ciol., 3: 1007-1015.

22. Egerton, P. H., 1864: Journal of a Tour through Spiti. London: Cundall Downes.

$2 \rightarrow$ Featherstone, B. K., 1926: The Biafo Glacier. Geogr. J., 67: 351-354.

24. Finsterwalder, R., 1935: Forschung am Nanga Parbat. Hannover: Helwing. 143 pp.

25. - 1937: Die Gletscher des Nanga Parbat. Z. Gletscherk., 25: 57-108.

26. - , 1960: German glaciological and geological expeditions to the Batura Mustagh and Rakaposhi Range.J. Glaciol., 3: 787-788.

27. Finsterwalder, R. and Pillewizer, W., 1939: Photogrammetric studies of glaciers of High Asia. Himalayan J., 11: 107-113.

$2 \rightarrow$ Freshfield, D. W., 1902: The glaciers of Kangchenjunga. Geogr. J., 19: 453-475.

$2 \rightarrow$ Geographical Journal, 1925: The movements of Indian glaciers. 66(4): 331-334.

30. - 1955: The glaciers of the KuluLahul-Spiti watershed. 121: 117-119.

31. Gilbert, L. B. and Auden, J. B., 1933: Note on a glacier in the Arwa Valley, British Garwhal. Rec. Geol. Surv. India, 66(3): 388404.

$3: \rightarrow$ Godwin-Austen, H. H., 1864: On the glaciers of the Mustagh Range. J. Roy. Geogr. Soc., 34: 19-56.

33. Gordon, T. E., 1876: The Roof of the World. Edinburgh: Edmonston and Douglas.

34. Grant, I. H. L. and Mason, K., 1940: The Upper Shyok Glaciers, 1939. Himalayan J., 12: 52-63. 
35. Gregory, C. E. C., 1932: The Shyok icebarrier in 1931. Himalayan J., 4: 67-74.

36. Griesbach, C. L., 1891: Geology of the Central Himalayas. Geol. Surv. India, Mem., 23: 27, 30, 33, 155, 170, 208-209; pl. 14, 16, $17,19,22,22 \mathrm{~A}$.

37. Grinlinton, J. L., 1912: Notes on the Poting Glacier, Kumaon Himalaya, June 1911. Rec. Geol. Surv. India, 42: 102-126.

38. - 1914: Notes on some glaciers of the Dhauli and Lissar Valleys, Kumaon Himalaya, Sept. 1912. Rec. Geol. Surv. India, 44(4): 280-335.

39. Gunn, J. P., 1930: The bursting of the Chong Kumdan Dam. Himalayan J., 2: 3537.

40. Gunther, A. E., 1954: The glaciers of the Kulu-Spiti Divide. Alp. J., 59: 288-298.

41. Hayden, H. H., 1907: Notes on certain glaciers in Northwest Kashmir. Rec. Geol. Surv. India, 35: 127-137.

$4: \rightarrow$ Hedin, S., 1910: The Kumdan Glaciers in 1902. Geogr.J., 36: 184-196.

43. Heim, A. and Gansser, A., 1939a: The Throne of the Gods. New York: Macmillan. $233 \mathrm{pp}$.

44. —, 1939b: Central Himalaya. Densk. Schweiz. Nat. Ges., Mem. Soc. Helv. Sci. Nat., 73: 132.

45. Henderson, A., 1859: Memorandum on the nature and effects of the flooding of the Indus, 10th Aug. 1858, as ascertained at Attock. J. Asiatic Soc. Bengal, 28: 199-228.

46. Hewitt, K., 1967: Ice front deposition and the seasonal effect: a Himalayan example. Inst. Brit. Geogr. Trans., 42: 93-106.

47. —_ 1969: Glacier surges in the Karakoram Himalaya (Central Asia). Can. J. Earth Sci., 6: 1009-1018.

48. Himalayan Journal, 1932: The Karumbar Glacier. 4: 182-184.

49. Hodgson, J. A., 1822: Journal of a survey to the heads of the rivers Ganges and Jumna. Asiatic Res., 14: 60-152.

50. Hunt, J. and Cook, C. R., 1938: A winter visit to the Zemu Glacier. Himalayan J., 10 : 49-70.

51. Indian National Committee for the IGY, 1961: Report of Indian National Committee. New Delhi.

52. Izzet Ullah, Mir, 1825: Travels beyond the Himalaya. Calcutta Quart. Orient. Mag., 3.

53. - 1842: Travels beyond the Himalaya. J. Asiatic Soc. Bengal, 7: 297.

54. Jangpangi, B. A., 1958: Study of some of the central Himalayan glaciers. J. Sci. Indust. Res., 17a(12) suppl.: 91-93.

55. Jangpangi, B. S. and Vohra, C. P., 1962:
The retreat of the Skunkalpa (Ralam) Gla cier in Central Himalaya, Pithoragarh Dis trict, Uttar Pradesh, India. In: Variations of the Regime of Existing Glaciers: Sympo. sium of Obergurgl, 10 September-18 September 1962. Commission of Snow and Ice, Int. Assoc. Sci. Hydrol. Publ., 58: 234-238.

56. Johnson, W. H., 1867: Report on his journey to Ilchi, the capital of Khotan, in Chinese Tartary.J. Roy. Geogr. Soc., 37.

57. Journal of the Japanese Society of Snow and Ice (Sepyo), 1976: Glaciers and climates of Nepal Himalayas. 38, Special Issue.

58. Kick, W., 1956: Der Chogo-LungmaGletscher in Karakoram. Z. Gletscherkd. Glazialgeol., 3: 335-347.

59. __ 1960: The first glaciologists in central Asia.J. Glaciol., 3:(28): 687-692.

60. _- 1962: Variations of some central Asiatic glaciers. In: Variations of the Regime of Existing Glaciers: Symposium of Obergurgl, 10 September-18 September 1962. Commission of Snow and Ice, Int. Assoc. Sci. Hydrol. Publ., 58: 223-229.

61. , 1964: Der Chogo-Lungma-Gletscher in Karakoram II. Z. Gletscherkd. Glazialgeol., 5: 19-24.

62. , 1972: Auswertung photographischer Bilder für die Untersuchung und Messung von Gletscheranderungen. Z. Gletscherkd. Glazialgeol. 8: 147-167.

63. Knight, E. F., 1893: Where Three Empires Meet. London: Longman's and Co.

64. Krenek, L. and Bhawan, V., 1945: Recent and past glaciation of Lahaul. Indian Geogr.J., 20(3): 93-102.

65. Kurien, T. K. and Munsi, M. M., 1962: Sonapani Glacier of Lahaul, Kangra District, Punjab, India. In: Variations of the Regime of Existing Glaciers: Symposium of Obergurgl, 10 September-18 September 1962. Commission of Snow and Ice, Int. Assoc. Sci. Hydrol. Publ., 58: 239-244.

66. LaTouche, T. H. D., 1910: Notes on certain glaciers in Sikkim. Rec. Geol. Surv. India, 60(1): 52-62.

67. Loewe, F., 1961: Glaciers of Nanga Parbat. Pakistan Geogr. Rev. 16(1): 19-24.

68. Longstaff, T. G., 1910: Glacier exploration in the eastern Karakoram. Geogr. J., 35: 622-658.

69. Ludlow, F., 1929: The Shyok Dam in 1928. Himalayan J., 1: 4-10.

70. Lynam, J. P. O'F., 1960: The Kulu-LahulSpiti watershed. Geogr. J., 126: 481-482.

71. MacBryde, D. H. and others, 1964: Scientific Report of Studies Carried Out on the Minapin Glacier by Members of the Cam- 
bridge Expedition to Nair, Karakoram, 1961. Cambridge: Cambridge University.

72. Mason, K., 1929: Indus floods and Shyok glaciers. Himalayan J., 1: 10-29.

73. _ 1930a: The glaciers of the Karakoram and neighbourhood. Rec. Geol. Surv. India, 63(2): 214-278.

74. - 1930b: The Shyok flood-a commentary. Himalayan J., 2: 40-47.

$7 ! \rightarrow-, 1935:$ The study of threatening glaciers. Geogr. J., 85: 24-41.

76. —_ 1940: Discussion, p. 426, of Karakoram 1939 by E. Shipton. Geogr. J., 95: 409-427.

77. Mercer, J. H., 1963: Glacier variations in the Karakoram. Glaciol. Notes, 14: 19-33.

78. , 1975a: Glaciers of the Karakoram. In Field, W. O. (ed.), Mountain Glaciers of the Northern Hemisphere, vol. I. U. S. Army CRREL Publ., 372-410.

79. , 1975b: Glaciers of the Himalaya. In Field, W. O. (ed.), Mountain Glaciers of the Northern Hemisphere, vol. I. U. S. Army CRREL Publ., 411-448.

80. Miller, M. M., 1965: Mount Everest and the Mahalangur Himal 1963. Explor. J., 43(3): 130-148.

81. - 1966: Tritium in Mt. Everest Ice. $J$. Geophys. Res., 10: 3885-3888.

82. - 1970: Glaciology of the Khumbu glacier and Mt. Everest. In: Research Reports 1961-1962. Washington, D. C.: National Geographic Society, 153-163.

83. Mitchell, J. W. A., 1894: Unpublished notes in the Purkia Dak Bungalow Log Book.

84. Müller, F., 1958: Eight months of glacier and soil research in the Everest region. In Barnes, Malcolm (ed.), The Mountain World. New York: Harper and Brothers, 191-208.

85. Munsi, S. K., 1965: Geomorphology of the Billing Lumpa Valley and the Gangstang Glacier. Geogr. Rev. India, 27(3): 135-143.

86. Neve, E. F., 1910: Mt. Kolahoi and its northern glacier. Alp. J., 25: 39-42.

87. Odell, N. E., 1963: The Kolahoi Northern Glacier, Kashmir.J. Glaciol., 4: 633-635.

88. Oestrich, K., 1911: Der Tschochogletscher in Baltistan. Z. Gletscherkd., 6: 1-30.

89. Oldham, R. D., 1904: Note on the glaciation and history of the Sind Valley, Kashmir. Rec. Geol. Surv. India, 31(3): 142-161.

90. Paffen, K. H., Pillewizer, W., and Schneider, H. J., 1956: Forschungen im Hunza-Karakorum: Vorlänfiger Bericht über die Wissenschaftlichen Arbeitender Deutsch-Österrichischen Himalaya-Karakorum-Expedition, 1954. Erdkunde, 10: 15-
28.

91. Pfannel, H., 1904: Von meiner Reise zum K-2 den Bergen Baltistans. Mitt. Geogr. Ges. Wien, 47: 247-260.

92. Pillewizer, W., 1956: Der Rakhiot-Gletscher am Nanga Parbat in Jahre 1954. Z. Gletscherkd. Glazialgeol., 3: 181-194.

93. —_ 1958: Neue Erkonntrisse über die Blockfewegung der Gletscher. Z. Gletscherkd. Glazialgeol., 4: 23-33.

94. Raina, V. K., 1963: A note on some glaciological observations in the Garwhal Himalaya. Indian Minerals, 17(2): 159-163.

95. 1971: The snout of the Machoi Glacier, Kashmir. Rec. Geol. Surv. India, 96: 51-54.

96. Raina, V. K., Bhattacharya, V., and Pattnaik, S., 1973: Zemu Glacier. Rec. Geol. Surv. India, 105(2): 95-106.

97. Roosevelt, T. and Roosevelt, K., 1926: East of the Sun and West of the Moon. New York: Scribner. 284 pp.

98. Schlagintweit-Sakunlunski, H. V., 1880: Reisen in Indien und Hochasien. Jena: Hermann Costenoble. 4 Vols.

99. Schneider, H. J., 1969: Minapin-Gletscher und Menschen im NW-Karakorum. Die Erde, Jahr 100, 2-4: 266-286.

100. Schomberg, R., 1934a: The glaciers of upper Ishkomen. Alp. J., 46: 344-350.

101. , 1934b: The Bar and Daintar glaciers. Alp. J., 46: 131-142.

102. Scientia (Kexue Tongbao), 1973: Natural features and geologic history of the Mt. Everest area, southern Tibet, China. Tibetan Scientific Expedition, Academia Sinica. Translated from Kexue Tongbao, 18: 11-21.

103. Shaw, R., 1871: Visits to the High Tartary Yarkand and Kashgar (Formerly Chinese Tartary) and Return Journey over the Karakoram Pass. London: John Murray.

$10 \rightarrow$ Smythe, F. S., 1932: Explorations in Garwhal around Kamet. Geogr. J., 79: 1-11.

105. Srikantia, S. V. and Padhi, R. N., 1963: Recession of the Bara Shigri Glacier. In: Symposium on Himalayan Geology. Geological Survey of India, 97-100.

$10 \rightarrow$ Stein, A., 1909: Explorations in Central Asia. Geogr.J., 34: 241-271.

$10 \rightarrow$ Strachey, H., 1853: Physical geography of western Tibet. J. Roy. Geogr. Soc., 23: 1-69.

108. Strachey, R., 1847: A description of the glaciers of the Pindur and Kuphnee rivers in the Kumaon Himalaya. J. Asiatic Soc. Bengal, 16: 794-812. Or 1848: Edinburgh New Philosoph. J., 44: 108-122.

109., 1848 : Note on the motion of the gla- 
cier of the Pindur in Kumaon. J. Asiatic Soc. Bengal, 17: 203-205. Or 1849: Edinburgh New Philosoph. J., 45: 258-262.

$11(\rightarrow-, 1900 \mathrm{a}:$ Narrative of a journey to the Lakes Rakas-Tal and Manasarowar in Western Tibet, undertaken in September, 1848. Geogr.J., 15: 150-170, 411-415.

111. Tewari, A. P., 1969a: Further retreat of the snout of the Pindari Glacier. Indian Scientific Congress Association, 56th Session, Procedures, 3: 245.

112. , 1969b: Study of the Burghal Maiktoli Glaciers, Kumaon Himalaya. Indian Scientific Congress Association, 56th Session, Procedures, 3: 246.

113. , 1969c: On the study of the snout of the Mrigthuni Glacier and geomorphological studies of the Sukhram Sunderdhunga Valley. Indian Scientific Congress Association, 56th Session, Procedures, 3: 246.

114. , 1970: Study of the Gangotri Glacier (Uttar Koshi District). Indian Scientific Congress Association, 57th Session, Procedures, $4: 84$.

115. - 1971: A short report on glacier studies in the Himalayan Mountains by the Geological Survey of India. Stud. Geomorphol. Carpatho-Balcancia, 5: 173-181.

116. , 1973: Recent changes in the position of the snout of the Pindari Glacier (Kumaon Himalaya), Almora District, Uttar Pradesh, India. In: The Role of Snow and Ice in Hydrology, Proceedings of the Banff Symposia, September 1972, vol. 2. Unesco-WMOIAHS, 1144-1149.

117. Tewari, A. P. and Jangpangi, B. S., 1962: The retreat of the snout of the Pindari Glacier. In: Variations of the Regime of Existing Glaciers: Symposium of Obergurgl, 10 September-18 September 1962. Commission of Snow and Ice, Int. Assoc. Sci. Hydrol. Publ., 58: 245-248.

118. - 1972: Note on the study of the Kaphni Glacier, Kumaon Himalaya, Almora District, U.P. Rec. Geol. Surv. India, 99(2): 35-40.

119. Thomson, T., 1852: Western Himalaya and Tibet. London: Reeve and Co.

120. Vigne, G. T., 1842: Travels in Kashmir, Ladak, Iskardo, the Countries Adjoining the Mountain-course of the Indus, and the Himalaya North of the Panjab. London: Henry Colburn.

121. Visser, P. C., 1928: Von den Gletschern am obersten Indus. Z. Gletscherkd, 16: 169 . 229.
122. —— 1932: Gletscherüberschiebungen im Nubra-und Shyock-Gebat des Karakoram. Z. Gletscherkd., 20: 29-44.

123. , 1934: The Karakoram and Turkistan Expedition of 1929-1930. Geogr.J., 84: 281-295.

124. Visser, P. C. and Visser-Hooft, J., 1938: Karakoram: Wissenschaftiche Ergebnisse der Niederlandischen Expeditionen in den Karakorum und die angrenzenden Gebiete in den Jahren 1922, 1925, 1929/30 und 1935. Band 2. Leiden: E. J. Brill.

125. Vivian, M. R., 1970: Sur quelques aspects de la glaciation Himalayenne au Nepal. Assoc. Geogr. Francaise Bull., No. 379-380: 67.77 .

126. Walker, H. and Pascoe, E. N., 1907: Notes on certain glaciers in Lahaul. Rec. Geol. Surv. India, 35(4): 139-147.

127. Warren, C., 1934: The Gangotri Glacier and Leo Pargial, 1933. Alp.J., 46: 306-320.

128. Washburn, A. L., 1939: Karakoram glaciology. Amer. J. Sci., 237: 138-146.

129. Wiche, K., 1958: Die Österreichische Karakoram-Expedition 1958. Mitt. Geogr. Ges. Wien, 100: 280-294.

130. Wilson, A. C., 1875: The Abode of Snow. New York: G. P. Putnams.

131. Wissmann, H. von, 1959: Die Heutige Vergletscherung und Schneegrenze im Hochasien, mit Hinweisen auf die Vergletscherung der Letzen Eiszeit. Akadamie Wissenschaften und der Literatur in Mainz, Abhandlungen der Math.-Naturwissenschaftlichen Klasse, Jahrg. 14, 1105-1407.

132. Wood, H., 1922: Explorations in the eastern Karakoram and the Upper Yarkand Valley. Narrative Report of the Survey of India.

133. Workman, F. B. and Workman, W. H., 1910: The Call of the Snowy Hispar. London: Constable and Co. 297 pp.

$13 \rightarrow$ Workman, W. H., 1905a: From Srinagar to the sources of the Chogo Lungma Glacier. Geogr.J., 25: 245-268.

$13 \rightarrow-, 1910$ a: The Hispar Glacier: Prominent features of its structure. Geogr. J., 35: 115-132.

$13 \rightarrow-, 1910 \mathrm{~b}$ : The tongue of the Hasanabad Glacier in 1908. Geogr. J., 36: 194-196.

137. Workman, W. H. and Workman, F. B., 1917: Two Summers in the Ice-wilds of Eastern Karakoram. New York: E. P. Dutton.

138. Younghusband, F., 1896: The Heart of a Continent. London: John Murray. 246 pp.

Ms submitted May 1978 